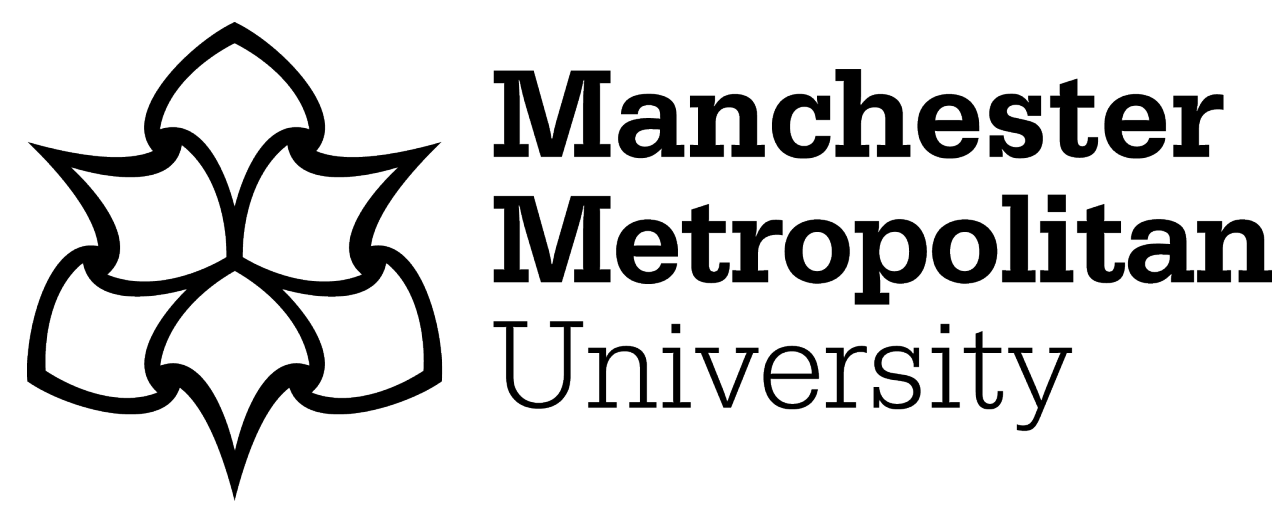

Zubair, S and Zubair, M ORCID logoORCID: https://orcid.org/0000-00019199-6576 (2017) Situating Islamic feminism(s): Lived religion, negotiation of identity and assertion of third space by Muslim women in Pakistan. Women's Studies International Forum, 63. pp. 17-26. ISSN 0277-5395

Downloaded from: https://e-space.mmu.ac.uk/622460/

Version: Accepted Version

Publisher: Elsevier

DOI: https://doi.org/10.1016/j.wsif.2017.06.002

Usage rights: Creative Commons: Attribution-Noncommercial-No Derivative Works 4.0

Please cite the published version 


\section{Situating Islamic Feminism(s): Lived religion, negotiation of identity and assertion of third space by women in Pakistan}

\section{Abstract}

\section{Abstract}

This paper reports the findings of an exploratory, qualitative study with Pakistani women to explore how Muslim women studying English in higher education contexts in Pakistan engage with feminist thought. The broader aim of the study was to capture the relationship between these women's 'secular' education and their religious (and secular) social identities as young, urban, middle class working women in a Pakistani higher education context. In particular, the study sets out to explore how Pakistani women at higher education institutions interact with and use 'new' forms of knowledges, particularly those dominated by western frameworks of intellectual thought and reasoning, in the context of their own potentially different social lives and self-identities as Muslim women. The findings show that the young women academics in addition to negotiating with the Western notions of Feminism also simultaneously challenge the indigenous patriarchal hegemonies and conservative religious discourses in their social context by attempting to rework notions of Muslim women's identity in Pakistan, envisaging what Bhabha has termed a third space. 
Situating Islamic Feminism(s): Lived Religion, Negotiation of Identity and Assertion of Third Space by Women in Pakistan

\begin{abstract}
This paper reports the findings of an exploratory, qualitative study with Pakistani women to explore how Muslim women studying English in higher education contexts in Pakistan engage with feminist thought. The broader aim of the study was to capture the relationship between these women's 'secular' education and their religious (and secular) social identities as young, urban, middle class working women in a Pakistani higher education context. In particular, the study sets out to explore how Pakistani women at higher education institutions interact with and use 'new' forms of knowledges, particularly those dominated by western frameworks of intellectual thought and reasoning, in the context of their own potentially different social lives and self-identities as Muslim women. The findings show that the young women academics in addition to negotiating with the Western notions of Feminism also simultaneously challenge the indigenous patriarchal hegemonies and conservative religious discourses in their social context by attempting to rework notions of Muslim women's identity in Pakistan, envisaging what Bhabha has termed a third space.
\end{abstract}

Keywords: Islam, feminism, Pakistan, postcolonial, women, identities 


\section{Introduction}

Pakistan occupies a central place in the current global debates about gender and Islam. Not only have 9/11 and recent attacks on Malala Yousafzai and girls's schools in Northern Pakistan by the Taliban generated a lot of interest within the Western academia on the linkages between gender and Islam, some Western countries have actually taken actions to uproot those cliches and practices that supposedly weaken women in Islamic countries. Therefore the issue of gender has also come up in recent geopolitical campaigns and gained importance in the international relations with Islamic countries (Raihaneh 2016). This paper brings forth the voices of Pakistani women academics, their engagement with English Literature and feminist literary texts and theories in relation to their own social and familial roles, their preoccupation with pressing issues of their rights and duties as intellectual women. who engage with issues of relevance of feminist epistemology and gender equity to their own lived lives in contemporary Pakistan. By debunking the myth of the veiled and domesticated Pakistani woman, the research foregrounds the subaltern voices of a group of intellectual women-- albeit small in number-- which hitherto remain invisible or seldom heard in western discourses and media representations. This research seeks to fill a wide gap in existing knowledge about the multiple and shifting identities of young intellectual women living and working in Pakistan. It also purports to make significant contributions to the current global debates about gender and Islam, race and ethnicity, Islamic and transnational feminist studies.

This paper focuses on the theme of reception practices surrounding the dominant western ideologies within the current postcolonial Pakistani context - particularly one characterized by new global and transnational connections, structural inequalities and 
hierarchies of power, with the related resurgence of strong ethno-religious and national affiliations and identities. Using data from focus groups and participant observation, we illustrate the complexities and ambivalences the teaching and learning of English Literature creates for (young) women within this context, specifically in relation to their own parallel and intersectional gender identities, social locations and positionings within Pakistani society, state and culture. The narratives of young female academics are cited to deconstruct : the hegemony of imperialist knowledge and patriarchal religio-political discourses within institutions of higher education as well as the hegemony of white feminists. Pakistani women's assertions of a third space, their engagement with white feminists' ideals and their perceived western notions of autonomy and independence viz-a-viz the construct of free women(discussed below) signify a departure from and a reaction to the imperialistic agenda of a monolithic and universal Feminism (with a capital F). They also come out with a strong and forceful critique and rejection of indigenous patriarchical discourses and monolithic hegemony of male clerics over Islamic jurisprudence.

\section{Postcolonialism and Transnational Feminism}

We ( a collective we for the reserachers and their participants) in postcolonial Pakistan contend that our indigenous ( decolonized) identities are highly at stake if we keep on promoting the epistemological hegemony of white men (and women) at the center of knowledge and marginalising ourselves at the periphery. To understand what feminism means to people in Pakistan, we need to look at it as reminiscent of the colonial rule, sexual liberation and autonomy of women in the West, while also keeping in view the polarizations within Pakistani society between extremist groups and unveiled or anglicized women. 
The western discourses on Muslim women remain reductive by ignoring the wide variety and diversity of women as individuals within any given culture by constructing a monolith Muslim 'other' with intellectual, professional and working women being no exception to this general rule. Jeffery 's ( 1979) work titled: Frogs in a Well, is a telling example wherein the title itself is deprecating followed by a list of contents on purdah-observing Muslim women which reads: Behind the curtain; Pirzada women; Islam and the Seclusion of women; Complaining and complying; the tribulations of life at home; The trials of going out; The two faces of Burqa. In a similar vein, representations of Malala (Yousafzai and Lamb 2013) and Mukhtar Mai ( Mai and Coverdale 2007) by their orientalist co-authors in their (auto)biographies are cases in point where they are positioned as poor, weak, oppressed and backward. Elsewhere, as Afzal-Khan points out (2015) the 'individual heroine syndrome' is promoted by celebrating individual women like Malala and Mukhtar Mai, who somehow rose above these limitations by virtue of their extraordinary capabilities, strength and drive. As Afzal-Khan observes:

Today, as a cover for imperialism at home and abroad, white middle class feminism directs its appeals to young white women (and women of color from erstwhile colonies aspiring to western privilege) through the rhetoric of individual selfempowerment. This rhetoric is used to cover up western imperialist ideology when western nations invade/bomb Muslim lands like Afghanistan and Northern Pakistan , in the name of rescuing oppressed Muslim women who can then be mobilized to empower themselves as individuals with the help of western feminism and 'aid', in the process becoming model subjects of Empire (2015:152).

Teaching feminisms and feminist texts has thus been not overtly political but also invariably politicized in such patriarchal, peripheral contexts as feminist thought challenges and threatens the dominant discourses, and tends to decolonize epistemology from this inherent imperialist desire( Davis: 2010). 
We problematize two issues surrounding transnational feminism: First, effectiveness in terms of theory and second in terms of practical application in the context of Mulsim women's lives in contemporary Pakistan. Recent theoretical debates have moved beyond the earlier concepts of global sisterhood to embrace postcolonial and transnational feminisms (Mendoza 2002; Ang 2003; Mohanty 1988). Mohanty's seminal article Under Western Eyes challenges the myth of universalistic notions of synthetic sisterhood and " the production of the Third World Woman as a singular monolithic subject in western feminist texts' :

This average third-world woman leads an essentially truncated life based on her feminine gender(read: sexually constrained) and being third world (read: ignorant, poor, uneducated, tradition-bound, religious, domesticated, family-oriented, victimized etc) . This, is in contrast to the (implicit) self-representation of western women as educated, modern, as having control over their own bodies and sexualities and the 'freedom' to make their own decisions (2003: 53).

Similarly, Ang (2003) argues that the otherness of other women once they come into selfrepresentation, works to disrupt the unity of 'women' as the foundation for feminism. After a close examination of the notion of transnational feminism, Mendoza (2002) observes that the notion still implies a global solidarity which transcends the boundaries of race, class, religion. In this sense it is quite similar to the earlier notion of global sisterhood which was questioned due to diversity in women's experiences in terms of race, class, nationality, geographical location, age and religion. Hence, the notion is tied in inextricably to the notion of a globalized world and the concepts of globalization, neo-colonialism, eurocentricism, postcolonial feminisms as well as diaspora identities. We draw on Mendoza's theoretical insights on transnational feminism to highlight our participant's engagement with the Western feminist epistemology illustrating that the term itself like its twin term global feminism is a slippery one when applied to actual practices in diverse contexts as has also been shown by Mendoza's analysis of the practices in Latin America. Similarly our participants in their particular social context in Southern Punjab may be able to engage with the theoretical terms 'exhibiting 
rhetorical agency ' ( Sinha 1999) but such epistemes implying universal feminism cannot be unproblemmatically coerced into actual practice as it can lead to serious consequences such as death threats , violence and harassment, social ostracization, loss of jobs, charges of blasphemy ( Zubair 2016a).

Before moving on to present the research methodology and data, it would be pertinent to give the reader a brief overview of the concept of Islamic feminism as it is used in the current literature.

\section{Islamic Feminism}

As pointed out above, the feminist movements in Pakistan are enmeshed in the global politics as well as polarizations and divisions in the country in terms of diverse groups, classes, genders and urban/rural populations. Raihaneh (2016) defines Islamic feminists as women who are trying to make changes to provide new interpretations of Quran and other Islamic texts. Similarly, the Pakistani feminist and women's rights activist Zia (2009) uses the term to refer to those feminists who are concerned with looking for empowerment within a 'rethought Islam' and are involved in reinterpreting and re-examining a masculinist reading of the Quran and Shariah. Scneider (2009) observes that muslim actors in local, national and transnational spaces argue that believing Muslims do not depend on religious authorities in order to understand the Quran for themselves, hence the global discourse of Islamic feminism is misleading as a singular movement with a common agenda .Zia (2009) goes on to argue that the indigenous secularist feminist movements in Pakistan have become diluted in their effectiveness due to discriminatory religious laws, dictatorships, NGO-ization, co-option by the state and political parties in the same way as the global women's movement has. She further contends that by allowing Islamic feminists to redefine the feminist agenda in Pakistan, the secular feminists have set a bad precedence which will lead towards the bifurcations of good vs bad Muslim woman; women who abide by the liberal interpretation of 
theology will be pitted against those following a strictly literal interpretist code and thus secular feminism will be rendered irrelevant. Hence, this new feminism is rooted in Islamic discourse,with its main objective to empower women within Islam and Islamic jurisprudence.

While scholars based in the West have focussed ( Mahmood 2005, Barlas 2013) on veil and piety movements viewing it as Muslim women's agency in relation to the sociocultural context of Muslim women's lived lives particularly in the western contexts, in the context of the actual lived realities of Muslim women's lives within Pakistan, this resurgent phenomenon appears to be far more complex and ambivalent. It was strategically and systematically promoted through the discourses on chaddar aur chaar diwaari (veil and four walls for women); popularized and imposed during the military dictatorship of General Zia during the early 1980s by the Council of Islamic Ideology, through strict control of the state media, the education policies and the textbooks. Almost two decades later, when Pakistan became an ally of the US during Musharraf's regime (1999-2007) in its war on terror, US funding came through in abundance for scholarships and research, educational reforms, revision of curricula, women development, opening of Women's Studies and American Studies Centers at the state-run universities. During the war on terror in the post 9/11 era, the West viewed the resurgence of veiling practices and piety movements in Pakistan as potentially threatening faith-based politics whereas for indigenous women faith-based feminism emerged as an alternative to the US sponsored women's rights discourse which reeked of neo-colonialist ambitions of a foreign power (Saigol 2016 ; Jamal 2005 ).

\section{Research Setting: Researchers and Participants}

Teaching of English Literature and language were used during the British rule in India to disseminate the language and culture of the colonizers. Within the current context of the rising religious fervor in the country, we, as feminist academics, based in Pakistan and the UK respectively--while one of us has taught English literature in Pakistan for three decades--- 
look for answers to the question of how young female academics (re)organise a sense of who they are across time and space; how they work with their multiple relationships with the world through their use of a foreign language, and engage in identity construction and (re)negotiation in inter and transcultural contexts; how they take new positionings between the self and the other in an in-between dialogical space, known as the third space (Bhabha 1994). Shahnaz Khan (1998) has used Bhabha 's concept of third space to theorize Muslim women's self-construction in Canada which is a diaspora context potentially very different from these women's indigenous Pakistani context. Later, while researching on Pakistani women in prisons suffering for adultery under Zia's Hadood Ordinance, Khan observes that her positioning as an academic based in the West researching on Pakistani women runs the risk of reproducing the Third World Woman as a spectacle for the orientalist gaze. She writes:

\begin{abstract}
Standing at the intersection of sexism and racism in Canada, I place this discussion in what I believe to be a productive tension between writing about the Zina Ordinance and its reading in the West. This tension could be described as a "third space," one of liminality. Homi Bhabha and bell hooks argue that the contradictions within this space allow for a renegoti ation of binary codes and predetermined boundaries, enabling critical inquiry and social change. Such a space also allows feminist responses to move beyond culturalist explanations, which simply reduce Pakistani women's subordination to gender or religion (2004:663)
\end{abstract}

Similarly, we ( the researchers and the researched in this study) may appear to be privileged in Pakistani society as professional women, by our middle class position, access to higher education and our English language ability, yet simultaneously we are feminized and treated differentially in comparison to our male colleagues and counterparts within the state institutions of family and education ( Zubair 2016a). The only difference --between the researchers and the research participants-- is that of the variables of age and generation in that the women in our study are young (22-30) and grew up in the era of General Zia's Islamization. 
Furthermore, a fundamental concern which we share with our research participants with regard to Feminism is that the 'official' version and definition of Feminism still come from the dominant groups i.e. the white, middle class feminists. Therefore, this research with young women academics is aimed at finding a voice for our indigenous narratives and discussions as well as to raise alternative, feminist voices within the predominantly patriarchal academy against the backdrop of rising religious extremism in this highly polarized Pakistani context where the teaching of feminist theories and texts has often been deemed immoral and even blasphemous ( Zubair 2016 a ). Our participant's discussions epitomize the larger struggles over issues of ( religious) identity and decolonization from ongoing cultural imperialism in a country torn apart—at this point in time-- by religious extremism, fundamentalism, obscurantism on the one hand and on the other by ever-shrinking space for the progressive human rights groups, secular women's movements and liberal academics. The teaching of English Literature with its focus on women's feminist voices is central to these competing voices and discourses as English is enmeshed in both the global and local politics because of its association with our colonial past, neo-imperialist Western powers, as well as the cultural hegemony of the local elite.

The research reported here was carried out at the department of English at Baha-ud-Din Zakariya University (BZU), in Southern Punjab, Pakistan. Southern Punjab has lately been in international news for religious extremism, backwardness in terms of women's literacy, development and participation in workforce. However, a significant shift in women's enrolment in HE programmes (including those in English) has been witnessed here during the past decade and a half with the numbers of women students and faculty rising along with 
the clamour for degrees in English. This led the department to introduce new research degree programmes like MPhil and Phd both in English Literature and Linguistics.

Currently, the department offers BS, MA, MPhil and Phd degrees in both Literature and Linguistics. Until the late nineties English Literature courses across the board in Pakistani universities were heavily dominated by canonical British literature, with the inclusion of only a few British women novelists like George Eliot, Jane Austen. Conspicuous by their absence were: discourses on feminist literary theories or women's writings capturing and representing life from a feminist perspective; representations of women's consciousness in their work as opposed to the male hegemonic representations of women in the predominantly patriarchal British literature. The late 1990s witnessed the inclusion of new courses (and genres including autobiographies, memoirs, life writings) on Women's Writings, Language Gender and Society, South Asian Literature as well as more white (black and coloured ) women's voices in the mainstream literature courses. New courses such as Feminist Linguistics, Feminist Stylistics emerged as part of the curriculum at the BS and MA levels in Applied Linguistics. This also coincided with the rising number of women students and women faculty.

The main objectives of the study included: a) Understanding how young, urban, middle class, working women of Muslim faith experience and negotiate identity shifts, if any, after taking on new public roles; b) Exploring the role if any, of 'new' forms of knowledges including feminist thought, in how these women make sense of their own changing social locations, lives and identities as women working and interacting within a mainstream public domain; c) Revisiting (Western) feminist epistemology and its meaning, interpretation and relevance for these Muslim women living and working in the Pakistani context.

The data comprises unstructured group interviews of 20 urban, middle class, professional women between 22-30 years of age, interviewed in groups of three to four. All 
of the women were familiar with the feminist theories and texts ( see note 1). Allof them were personally known to the first author; some were registered for MPhil/PhD research degrees and were working on their research projects under her supervision while two of them had completed their MPhil projects on gender and feminist theory and its application in the Pakistani context. Keeping in view the ethical concerns in research, they were briefed about the research study; consent was obtained prior to the audio recordings. After several year's acquaintance with the participants through supervision of their projects, a level of mutual comfort and understanding had developed between the researcher and research participants. Some of them had often confided in the first author, prior to the research study, about experiencing shifts in their personal identities, after studying feminist theories at the university. Some had also complained informally about the difficulties in communicating their true feelings and to share personal experiences of identity shifts with their families, as what they discussed formally in their classes while teaching, studying and researching English literature was often in conflict with the broader Pakistani cultural norms and values. Having known and taught, supervised and worked with the participants and their friendship networks, the convenience sampling method was used. Group discussions instead of individual interviews were used to ensure that they would be comfortable discussing such sensitive and personal issues among close friendship networks (Note 2).

It would have been worthwhile to introduce the readers to some participants in the study who feature in the discussions and excerpts cited in this paper. However, owing to potential repercussions of dire consequences in contemporary Pakistan ( threats and violence; loss of job ; ostracization by family and wider community; charges of blasphemy -a crime punishable by death sentence) the ideas expressed may invoke, the details given below have been obscured to ensure confidentiality of the information and safety of the participants (see Note 3). Hence, the names cited are fictitious. All the participants came from middle class background; 8/20 were daughters of highly educated, professional fathers such as university professors, doctors, 
engineers and home-maker mothers. A few (4/20) drove their own cars to the university, while a few others were escorted by their drivers or husbands in cars. In keeping with the Pakistani norms , all single women in the data (15/20) lived with their parents/families, while one woman living with extended family commuted on public transport to visit her parents over the weekends. Most of these young women did not cover their heads . Out of the entire research cohort of 20, only 2 women covered their heads with chaddar (drapes) while the rest wore a dupatta ( headscarf) which signifies haya ( modesty) in this region.

The main ideas expressed by them in the excerpts reproduced below are congruent with the views of the entire cohort. The focus group discussions resonate with similar themes and views therefore a few excerpts were chosen taking into account economy and clarity of expression.

There was evidence from earlier interviews with women in higher education (Zubair 2006) that their lives were strongly influenced by religion and patriarchy. However, the fact that these women had made a conscious decision of taking up employment after obtaining higher degrees, that they so frequently bonded with the author and other women on issues of women's rights and the curtailment of their individual freedoms by the family and patriarchy, appeared to be indicative of their agency. The idea was to capture these identity shifts through group interviews using self-reflexive methods, often used by feminist researchers (Parr 1998; Alldred 1998; Author 2005; Birch 1998). Thus reflexivity enabled us as researchers to combine and connect our own experiences with the research participants' voices . The notion of reflexivity in poststructuralist, feminist research rejects the fantasy of an authentic subject whose subjectivity is independent of, prior to or above culture (Alldred 1998).

As this paper looks at the representations of women's identities in their own narratives; the use of language and hegemonic concepts of the dominant culture are central to their discourse. Marginalized groups often point out that the dominant linguistic frameworks may be imbued with negativities for them (Spender 1985), such as, the phrases free women and 
azad khayal (free thinking), in English and Urdu respectively, signify value-laden patriarchal constructions of socially desirable and acceptable feminine behaviour. It would be pertinent to mention here that since there is no exact word or synonym for feminism in the indigenous languages, the word connotes a foreignness generally associated with the western cultures.

The following two prompts were used to initiate the group discussions, which were largely, unstructured and free-flowing.

1) Are you religious? Or would you define yourself as religious?

2) What is your take on feminism/s in our context?

It is important to mention here that these data were collected for a broader study which also explored women's interactions with and their perceptions of 'new' media images of women (Zubair 2016 b) . More importantly, these discussions took place in the context of texts and activities that were valuable to the women themselves, in which they had a positive identity as experts. Thus, this social context of academic research, made them comfortable expressing their various and often competing cultural identifications, social positionings, cultural values and concerns.

Methodologically, the paper is premised on Spivak's notion of the problemmatics of the agency and voice of the subaltern. Spivak (1988) reads the absence of women's voices in the colonial debates as representative of the difficulty of recovering subject positions in general and as indicative of the violence of colonialism and of indigenous patriarchy in particular: 'there is no space from where the subaltern (sexed) subject can speak' ( cited in Loomba 2003). The research draws on the Subaltern Studies group's emphasis on representation of local and diverse voices and the polemics surrounding the issue of Islamic versus secular feminism and indigenous movements for Muslim women in diverse Muslim contexts ( Aftaab 2008, Christina-Schneider 2009, Hassan 2002 , Mernissi 1987, Zia 2009). As discussed above, we take a self-reflexive, exploratory position to research with Muslim women in contemporary Pakistan rather than research on them. Within Linguistics and Discourse 
Studies, identities are believed to be typically signalled through language use. Therefore, focussing on the inescapable relevance of language to human behaviour and identity, this selfreflexive, participatory study carried out at BZU in Multan is an attempt to capture the fluidity, complexities and the lived realities of Muslim women's lives through their talk. Further, taking cue from scholars of Religion Studies like Neitz (2004) and Wuthnow ( 2011) who look at narrative as constitutive of identity, use of narrative data from focus group discussions and informal talk is used to highlight Pakistani Muslim women's own (re)constructions and representations of their changing roles, positionalities and identities; and how these interlink with their lived experiences of religion and Muslim patriarchy in a postcolonial, post 9/11 Pakistani Muslim, as well as in a globalised world context. Pointing to the particular significance of religion and religious identities within this specific sociopolitical context and social lives of these young women, this data reveals a strategic reconfiguration and reconceptualization of the ideas associated with western feminisms, gleaned through reading and researching literary texts. These urban, middle-class, working women while engaging with Western feminist epistemology also simultaneously harbour reservations towards it and often tend to distance themselves from white feminisms, thus asserting their continued commitment to their own separate identities.

In the sections that follow, the major themes in relation to the women's gendered and religious identities that emerged from women's narratives are analyzed. Our analysis is informed by Anthony Gidden's (1994) observation that human agency and social structure act through each other. We are aware of not over-emphasizing the agency of these women as individuals, as the data suggests that religious and societal structures do frame individual choice and action: external factors shape, form, and constrain their choices, although these structures are far from being all-powerful (adapted from Willett 2008). 


\section{I am not a religious person : Negotiating religion}

Although religion remains a significant identity marker in women's talk, it is not a monolith: women tend to speak for themselves reinventing their religious identities as different from the pre-given patriarchal constructs. They construct diverse as well as individualistic religious identities, as illustrated by the excerpts that follow, not a monolith or universal identity. By deconstructing patriarchy, challenging the hegemonies of Muslim clerics' control of epistemological constructs, these young, professional women are engaged with ongoing interactions with feminism and feminist theory in their everyday lives and social roles; creating alternative sites for defining themselves as they deem fit with respect to their varied social roles and not what the Muslim clergy decide.

Some excerpts on their religious positioning are being reproduced below to illustrate women's engagement with the pressing issue of their religious identities as Muslims. For instance Mehr who had been a single working woman for the past seven years, constructs an ongoing spiritual identity based on her own understanding of religion:

Well, I am not a religious person, I do have faith in God but as far as dogmatic institutionalized religion is concerned, I do not believe in that I do not believe in those, in that institutionalized dogmatic religion is just another way to exploit or to rather reinforce the normative hegemonies that already exist in society...though I do have strong faith in God but the way it is being signified by our religious clerics, the mullahs (Muslim clergy) and the men in general I do not believe in that...

Here, Mehr draws a distinction between being a religious person or just having faith in God. She articulates and challenges male hegemony over control of religion by suggesting that her own focus is on spirituality and faith as opposed to a religion which she constructs as being tainted by male control and hegemonic constructions. She makes here a rather bold and confident statement (with respect to the Pakistani context) about not being a religious person, but simultaneously legitimizes this divergence from religion through an emphasis on her continued belief and faith in God. Hence she presents her religious divergence as being in essence a rejection of male hegemony rather than rejection of a belief in God. Similarly, another 
participant, Qudsia asserts a religious identity but positions her own religiosity in relation to her love of God rather than the traditional preachings of the male Muslim clergy and patriarchal texts.

I do think, it may be farfetched, but I do think I'm religious...I often try to offer namaz (Muslim prayer) when I feel like which is quite often...I'm not insecure about that...one thing that strikes me is that religion as it reaches us is a bit distorted in its insistence on fear God, fear God, fear God,and I found it much better to love and...I literally thought each time it rained I thought whenever my mood is off God sends rain...for the longest time I thought I was God's favourite people and I still believe that...

Her words, it may be farfetched, suggest an awareness that others, following the more traditional religious interpretations and/or practices may not be in agreement with her views. She, nevertheless, legitimizes her own belief in religion and attempts to do away with the perceived excessive control exerted by structured, formalized forms of religion. This is particularly through an emphasis on her own authentic, lived, experience of religion which she positions as being in opposition to religious dogma. Her discourse focusing upon lived emotions and relationship with God, construct these as being superior to formalized religious practices, as enforced by the male clergy. A clear assertion of religious authenticity and a strong authenticated Muslim identity is evident here, particularly through the suggestion of being among God's favourite people through being a true Muslim by heart and emotion. Thus, Qudsia's discourse also constructs a distinction between the enforced outwardly religious appearance in the form of structured religious practices and the true inner/private, emotional, religious 'self' which focuses upon a direct relationship with God. The latter is presented as being far superior and hence undermining the significance of public performances or displays of religion. In short, the significance of religion as a private matter, not for public enforcement or display, is evident here. These are highly gendered (re)constructions of religion as both Mehr and Qudsia contest the dominant male representations of religion and speak from their coexisting multiple positions and identities as educated women as well as a 'devout' Muslims. 


\section{Free Women in Chains: Sexuality, desire and power}

Some patriarchal Muslim texts deny overt enjoyment of sex particularly to women, while allowing a husband to use force to have sex with his wife even if she is unwilling. Sex is thus constructed as a husband's right and a wife's conjugal duty in return for naan, nafqa, (bread and maintenance) ( Metcalf 2002). Same-sex relationships or any extra-marital relationships are taboo. The punishment for homosexuality or adultery within the Pakistani state law has been death since the Zia regime. As Khan (2010) observes that by focusing on the fundamentals of Islam, according to Zia's Zina (illicit sex) Ordinance, illicit sex became a crime against the state in Pakistani law. Her research in Pakistani prisons shows how women's incarceration for zina is linked to issues of gender, social class and social and familial control of women's bodies through their sexuality. Women in the data were, nevertheless, questioning such patriarchal structures and social norms by articulating hidden sexual desires in their interviews and opening up discussion on taboo subjects like lesbianism and feminism. This agentive discourse and discussion was witnessed among these young women academics as they also reported having this agentive discourse with their female family members and re-negotiating their position on sensitive issues like female sexuality, romantic love, sexual relationships, and divorce:

Now I think I am beyond my sell-by date so I get to talk to my mother about these things. It often starts with religion I argue that why God made it (sex) if it weren't to be enjoyed ----- as I said our mothers were taught to be ashamed of it, like your husband is going to sleep with you in the night but in the morning not even going to sit on the same sofa...so you just end up feeling like a slut. They were treated like that....our mothers...let alone enjoy they would not even let anyone get the wind of it...I would have liked to have a lesbian relationship with a friend of mine, if it was halaal (permitted by God). (Qudsia)

Religion and religion-based legitimizations, however, remained central to this gendered discourse, and were carefully interwoven by the women within such discussions to convey and affirm their continued allegiance to their religious identities. In this way, the women seemed to be using religion strategically as a powerful tool and a resource available to them for resistance 
,much in the same way that it is used to control them through the drawing of boundaries for acceptable gender behaviours and norms. Within their specific social and structural context, religion thus becomes an important site for this gendered struggle and control, resistance and negotiations of identities and (in)equalities.

As one of our teachers said in the class: sometimes we are trapped in chains and often times we willingly keep ourselves in chains. In the family atmosphere, we've encircled ourselves within ----- we've restricted and limited ourselves.

Here women appear to have internalized the power to control and discipline their sexuality in keeping with the societal expectations. Therefore, for them, the concept of radical Feminism with its rejection of marriage and family is unacceptable. Fernea (1998) presents the notion of family feminism which she coined after her fieldwork in several Middle Eastern countries after meeting and interviewing Muslim women. Hence these Islamic feminists — unlike some of their indigenous secular and western counterparts--- expressed a desire to achieve equality not by challenging the patriarchal institution of family but to strive for more equality and rights within the family paradigm as the institution of family in Eastern cultures offers a very strong support system. Similar aspirations were expressed in an earlier study by many women studying at a university in Southern Punjab, Pakistan (Zubair 2006 ). Mehr used the metaphor of 'chains' which women wear willingly as they do not wish to disobey their parents. Mehr had wanted to go abroad to the US or the UK for her PhD. Although financially independent and desirous of pursuing a higher degree abroad, she willingly submits to the dictates of her family, particularly her father who would not allow her to go abroad on her own as a single woman. She willingly accepts his decision because she does not want to disobey her father.

Sajida, who was fascinated by her in-depth study of Dorris Lessing's The Golden Notebook, borrows the metahpor of free women as an epistemological construct exhibiting her awareness of English feminist theories as well as the limitations of these constructs in her own 
different social context, where free women or liberated women are highly charged terms. She claims to belong to the ontological construct of 'free women', yet simultaneously agrees to an arranged marriage not of her choice, and submits herself to the institution of the patriarchal family:

Free women itself is a construct...definitely the family has the traditional notions and somehow we don't have that freedom--we have to somehow conform--because family has its own expectations.

As the first author had supervised some of their research projects on gender and feminism, the informal conversations following the supervision sessions would invariably juxtapose competing discourses of their personal aspirations in constant collision with the family and social norms; after reading and carrying out research on feminism and gender, some labelled themselves as free women, which is a very negatively loaded phrase in the Pakistani social context. This phrase is also often used to refer to people who are liberal and hence perceived as disregarding social norms and socially prescribed boundaries of acceptable social behaviour, sometimes with the added negative connotations of their values and ideologies falling outside (or not taking account) of the boundaries of religion. The nearest synonym in Pakistani languages is azad khayal which literally means free thinking but suggests a whole range of discursive significations of a woman having no morals, and/or promiscuous. The free(dom of) thought (or being free thinking) is also considered to be as bad as actually being free women in practice. Hence there is social regulation and control over thinking as well as values and unpractised ideologies. Such social regulation and control over thinking and forms of belief makes the women unable to articulate freely (or without constraints) the changes in the personal 'self' that they seem to experience. Such articulations are constrained by language, social context and structural dynamics, so as not to disrupt the dominant hegemonic constructions of gender (including within religion). Hence, in the sections below, while talking of sexuality, sexual desire and sexual relationships, their articulations are (safely) couched in euphemisms 
such as it (sex) and physical relationships (sexual relationships). However, by calling themselves free women they create alternative sites or spaces as opposed to the existing, dominant, indigenous patriarchal paradigms since free women implies not only a critique of the dominant ideologies regarding women's social positioning, it is a construct which is imbued with the hegemonic symbols of the dominant feminist voices. Thus women create spaces where they renegotiate and discuss ( along with fellow researchers and colleagues, including the authors) both - the indigenous patriarchal constructs and the western feminist ideologies in their struggle to find a third way. Their self-construction as free women is an act of discursive or symbolic resistance in a context where even freedom to think or free-thinking is limited.

\section{This is allowed in religion: Situating feminism within Islamic framework}

However, this freedom to think or the agency that they seem to exhibit here is not similar to Mahmood's participants in her study of the mosque women in Egypt, since they primarily engage with theoretical issues arising from the feminist literature that they read or research. Furthermore, this 'theoretical activism' is far removed from both - women's secular movements in Pakistan which scholars like Zia ( 2009) consider to have been rendered irrelevant and invisible as well as the indigenous religious movements like the Jamaat-e-Islami women, who wear the hijabs and claim their rights within an Islamic jurisprudence. .Jamal (2009) observes :

Unlike the Islamic feminists in Iran, Jamaat women cannot be valorized as Islamic feminists. Indeed they reject such a description and insist on positioning themseleves in direct opposition to those they consider the representatives of feminism in Pakistan. On the other hand, neither are Jamaat women solely engaged in the construction of a pious or religious self like the Sunni women that Mahmood has drawn upon to argue for new forms of gendered agency,....(2009: 17)

She goes on to link this divide between the secular feminists and Jamaat women with the class struggles in Pakistan as most of the Pakistani feminists belong to a class of so-called ' secular 
progressives'; that was entrenched in Pakistani society through the colonial system of education and administration in which English language ability and access to Western culture was the prerogative of elite groups ( 2009: 23). It is not a coincidence, then, to note that invariably all Jamaat women she interviewed preferred to converse in Urdu even those who had been to 'English speaking ' institutions such as Kinnaird, Lahore or St. Joseph's, Karachi. Thus the ability to converse fluently in English and access to Western worldview and ideologies gained from reading of literary texts are crucial class-markers that differentiate our participants from the Jamaat women. While the Jamaat women reject Western notions of women's rights and modernity in Jamal's study cited above, the women in our study contest such communitarian and collective constructions of a monolithic Muslim woman's identity and present their own personalized and privatized modes of enacting their religious identities. Often times, elaborating upon religious identity, they talk of individual agency and spirituality which are Western concepts.

For these young women, the point of divergence is that of articulating feminist arguments within an Islamic framework, which - when articulated in this way-- are experienced as a much more effective means of challenging Muslim patriarchy and asserting their equal rights as women within the traditionally male-dominated public domains and spaces. Recent research ( Khurshid 2015) on Pakistani women shows how being a parhi likhi (educated) woman implies acquiring a privileged subject position making claims to middle class and Islamic morality, and engaging in specific struggles within, rather than against the institutions of family, community, and Islam. Similarly, many of the young women in their narratives point to the freedoms and equal rights that they are accorded within Islam as women, frequently drawing clear distinctions between the gendered societal expectations and norms of their culture and what is actually allowed within an authentic Islam. For instance, Fatima points out that: 
...the feminism which we talk about these days, that women should have freedom and stuff like that ...this is allowed in religion ----- we often manipulate religion to our own advantage but ----- generally these things are explained and accepted by religion but our society is not ready for these things...society opposes...don't do this, don't do that... although according to religion Islam, if needed, a woman can work outside her home...

The perceived ideals of 'white feminism' are, on the other hand, viewed with both suspicion and skepticism by these young women. Not only are the western ideals and frameworks deemed by the young women as not addressing appropriately their own concerns and needs as Muslim women, but these are also perceived-- in addition-- as reinforcing western ideological hegemonies within their own non-western Muslim context. These young women speaking from their multiple and intersecting social locations and positionings - not merely as gendered subjects exposed to English literature and feminist texts within higher education settings, but also as post-colonial Pakistani Muslim subjects living in an Islamic state within the current socio-political climate of post-9/11:

...no doubt I do know what my traditional notions ingrained in me have told me that what is meant by propriety...I do know about that but I do know what's the Other...the globalization, the feminist theories and all that, the other options that are available so I have to negotiate my concepts somewhere between these two because neither is perfect...the western, no, not at all. Those notions, that is another parallel hegemony...they themselves are getting rid of it...our traditional notions, we should do away with them but...to what extent this is something to be defined by us... (Mehnaz)

The above quotation captures the agency and resistance of Muslim women in higher education in Pakistan who-- looking for a third epistemological space-- resist the hegemony of the Muslim clerics as well as that of the white, middle class feminist'sepistemological hegemony while carving out multiple and competing identities for themselves. Thus challenging the western ' essentialist perception' of Pakistani women embedded in the dominant narratives of 'brown women need to be rescued from brown men'; 'white women 
as their saviours', or ' to lighten the brownness of these women's lives while using that same brownness to mobilize a narrative of other' (Charania 2011: 67).

Further, in the following two excerpts, we clearly get a critique of neoliberal, capitalist postfeminist discourse which resonates with McRobbie (2009)'s arguments that the images of women in the British postfeminist popular culture still objectify and sexualize women to attract consumers in a capitalist society like Britain. However, with the adage of 'my body, my right', this commodification is subsumed under the individual's rights discourse:

The western notions or the western images that are being rather reinforced through the media representations in our society is another kind of hegemony. We women living in Pakistan, we rather need to be beware of that and we are also a bit skeptic about those ----- I mean about the parallel hegemony that is being created because again that the binary does get reinforced here we have the religious ideals here we have the western ideals ----- of what it means to be a proper or a new woman...again we have to find something somewhere inbetween these two ideals... (Mehr)

Feminism is a kind of reaction specially in our culture it's not justified, it's not that real, I feel... to me it seems that feminism in our culture is forced...the western image of feminism in particular... (Qudsia)

As can be seen in the quotes above, discussing the western model of feminist epistemology, the women articulate a desire and a need for a 'third space' to situate their own brand of Islamic feminism. They argue that the various models and paradigms of western feminism cannot be un-problematically applied to a context which has a different cultural history, particularly a socio-religious context where women's empowerment needs to be conceptualized differently, creating different scenarios for achieving gender fairness and women's empowerment. The dichotomous categorization of Pakistani Muslim and western cultural values and social contexts, and the respective oppositional positioning of $u s$ and them is evident in the women's discourses on gender and feminism as they emphasise their own 'difference' in identities and 
belonging, as Mouffe (1993) has pointed out that the definition of a 'we' always takes place in a context of diversity and conflict.

\section{Backstage \& frontstage identities}

There is consciousness among women of emergent conflicts in relation to their multiple social locations and shifts in identity formation as they enter the public, and hence male-dominated, domain of Pakistani higher education. As highly educated, career women who were economically independent these women were exposed to western worldviews and neoliberal discourses on women's freedom, equality and empowerment. However, in actual practice, the embodied public image a large majority of them projected through their particular choice of dress code, was that of a traditional embodied identity. Some $(2 / 20)$ of them covered their heads with dupattas (head scarves) while also wearing latest styles in Pakistani clothing from trendy and expensive designers, while others wore the scarves only around their necks but did not cover their heads. Although Muslim feminists like Mernissi would interpret the call for veil as a symbolic assertion of a distinct Muslim identity in the light of resurgence of ' Islam as one of the modern political forces competing for power around the globe'( 1987:33),wearing head scarves--traditionally and more specifically in the Southern Punjab context---signifies modesty and appropriate feminine behavior.

Furthermore, most of the women denied dating or having premarital sex. In fact, they expressed their own disapproval of dating or having sexual relationships, reported engaging in religious rituals and practices such as namaz (Muslim prayer offered five times a day) and roza (fasting during Ramadan). They_at times-- also expressed a strong resistance to adopting western feminisms, associating it both explicitly and implicitly with women's sexual freedom, and expressed their desire for a third theoretical space. The excerpts which are reproduced below are from a focus group recording with a group of women who do not cover their heads. 
These young women were among the very few who-- within the interview context-- admitted to dating men. They, nevertheless, resisted their own potential social stigmatization through an explicit distancing from western notions of dating (as well as the perceived western feminism) and their insistence on not 'crossing the limits' in terms of the acceptable sexual and moral regulations as defined and set by the perceived religious Islamic code:

Mehnaz: One of my students asked me in the class: madam, do you have a boyfriend? I just looked at him and said that first define a boyfriend in our context -----

Azra: In our society I think we have to consider the religious point of view as well... if they are doing something in the West it doesn't matter but if dating or something is happening here ----- we have to follow certain rules and regulations... we can't cross our limits...I am talking in a religious context ----here there are our religious limitations that you can meet the person, have lunch together but when it comes to physical relationship that is the limit...

As evident in the excerpt above, these young women's specific discourses on gender, women's sexuality, and dating heavily centered on their perceptions and lived experiences of their own different social and religious context which they explicitly differentiated from the West. Hence even as their own interactions with feminist texts, as part of their teaching and learning roles within the Higher Education sector, have enabled them relatively diverse and heterogeneous understandings of issues relating to women's sexuality--including their perception of 'different' Western models of gender and sexual emancipation, these young women appeared keen to protect their own self-image in public through an emphasis on the alignment of their own specific gender and sexual beliefs and practices with what they defined as the 'religious limitations' from an Islamic perspective. This discourse on their own religious and moral limitations was further reinforced by these young women as they contested and challenged the prevalent dominant public representations and categorisations of 'the religious woman', focusing once again on the different, and often contradictory, realities of their own lives and their own lived experiences of religion: 
Rashida: I feel that being religious is something else and the reality of our lives is something else....in our lives we don't fit into that definition of being religious women as such...because we may be asked to be in veils all covered up...The concept or the image of religious women that comes ...because I feel that it is related to your mindset, but people don't interpret it in those terms, the women who are fully covered she is going to be the religious woman but they don't think about the ideals that a woman is carrying in her head. For us to be religious means to have ideals of religion but to physically cover yourself that is something else.

The notion of 'ideals of religion' is significant in that these women's conceptualizations of 'being religious' are centered on their own individualistic interpretations which is a western concept as opposed to collective piety movements (such as Farhat Hashmi's dars congregations) and communal religio-political identities which generally characterize Pakistan as an Islamic state and society. Rather than accepting the dominant religious categorisations and representations which exclude these unveiled young women from a positive public identity and self-image of 'the religious woman', these young women, through their talk and use of specific discourses, actively engage in a collective process of reworking and renegotiating these religious definitions and boundaries (Bartkowski and Read 2003; Read and Bartkowski 2000). For these young women with their own multiple social locations and positionings - as highly educated and professional, working, Pakistani Muslim women - being religious is not merely about specific theological beliefs. On the contrary, their talk about religion and their own lived religious identities is tied up heavily with talk about their own morality, sexuality, family and cultural mores, as they draw culturally distinct ideological boundaries between their own concepts of dating and embodied practices of dress and those in the west and among their own veiled Pakistani Muslim counterparts respectively.

The data further reveals that these young women's occupation of multiple, and often contradictory, social roles and locations is not without its challenges. As Mouffe (1993:77) observes that:

The identity of such a multiple and contradictory subject is therefore always contingent and precarious, temporarily fixed at the intersection of those positions 
and dependent on specific forms of identification. It is therefore impossible to speak of the social agent as if we were dealing with a unified, homogeneous entity. We have rather to approach it as a plurality, dependent on the various subject positions through which it is constituted within various discursive formations;...( 1993:77).

Despite their engagement in collective boundary work and assertions of positive religious identities, the young women also continue to be faced with specific tensions in relation to the negotiation of their varied, shifting, backstage and frontstage social identities and respective social performances as they move within varied social contexts at a more individual level (Note 4). Such tensions between their traditional roles as Muslim women and as academics are particularly experienced by those young women who are engaged in teaching courses on gender and feminism. One young woman, for instance, articulates these tensions in the following excerpt pointing to how working women like herself have to contend with extra social pressures and feel a greater need to negotiate positive self-images, compared with men and their female counterparts who do not work.

I feel we have segments... with this person we can talk about this and with that person we can talk about this... there are compartments...we cannot portray ourselves freely what we are...for some we are like this for others like that...at work like this, with friends like that...we carry our image...being working women you have so many pressures on you as to what others think about you... (Rashida)

They are participating in what Wittgenstein would call different language games through which they make sense of the different worlds they inhabit and their conflictual roles and identities. Or as Mouffe (1993) has argued -- within feminist epistemology--for deconstructing the essentialist notion of identity as the necessary condition for an adequate understanding of the variety of social relations, where principles of equality and liberty should apply.

\section{Submission as agency}

Women repeatedly viewed submission to the patriarchal ideologies and norms as a form of agency. The following excerpt illustrates women's preoccupation with the theoretical constructs of structure and agency within patriarchy. 
Sajida: Submission is a form of agency because through submission you are somehow subverting those binaries...

Mehr: Submission is an agency in the sense that you detach yourself you simply take yourself out of the game so you simply cease to exist, you simply cease to contest those hegemonies, by detaching yourself making yourself aloof you are rising above and beyond these...so in that sense it can be regarded as an agency

Within their gender(ed) discourse, the young women repeatedly reconstruct submission to the patriarchal ideologies and norms as a form of agency. For them, submission or silence can be agentive and strategic and may be used as a form of resistance itself to the dominant culture of patriarchy.

These young women's specific reconstructions of submission as agentive and strategic are resonant of Bartkowski and Read's (2003: 79) analysis in relation to their Evangelical Christian female research participants in America whose positive discourses on wifely submission suggested that 'choosing' yourself to submit was in fact a rejection of "being trampled under foot, much like a doormat". The above excerpt from a focus group illustrates similar ideologies regarding 'willful submission' as being strategic and hence a form of agency.

Western feminist developmentalists find that many adolescent girls engage in a surface conformity rather than a complete acquiescence to womanhood's norms. Girls' differentiation between "what I think" and "what I really think" (Gilligan 1990: 4) reveals that they are able to resist hegemonic femininity on a psychological level. Similarly, these young women appear to deny here that they are actually really submitting to traditional patriarchal Islamic ideologies and practices in the strictest sense. Hence even though resistance against submission may be constrained for them in practice because of their disadvantaged locations within their specific social contexts, their denial of submission reveals a gender consciousness which is contrary to the more traditional Muslim ideologies of submission to the male patriarchs in the family. 
Furthermore, this denial also suggests that as they critically engage with the western feminist theories and constructs of individual freedom, women's rights, and gender fairness in and through their education and workplace, they are acutely aware and concerned about appearing backward or oppressed to others. It is, therefore, interesting as well as pertinent to note that these women need and use western theoretical concepts to articulate their gendered positioning within a traditional Muslim society like Pakistan. This seems to suggest that some of the western feminist concerns and feminist theories are perceived by them as being relevant to their own situations as women too (and also influencing their thinking to some extent as apparent from their denial that they are really actually submissive to patriarchy in the true sense) although the solutions put forward within western feminist paradigms in relation to emancipatory feminist practices may not be applicable or easily followed within these young women's specific social contexts. They, therefore, assert here some personal control and choice over their own lives and social relationships by suggesting that they only submit overtly on the face, but are able to engage in a covert, non-visible, form of resistance. For instance, Qudsia asked her mother : why God made sex if it was not to be enjoyed? And also articulated her hidden desire for a lesbian relationship: her act of consciousness-raising in relation to her mother through her rhetorical question, can be seen as a form of subtle resistance. This is because her question, by challenging the taken-for-granted gendered social norms and ideologies opens up a space for discussion and debate on an otherwise taboo topic within a more private and safer time and space shared with another woman - her mother. This is similar to what Sinha $(1999,208)$ refers to as women's 'rhetorical agency' in constructing new subject positions for themselves. Such agency, Jamal (2005) argues, can be understood properly by paying closer attention to the ideological and political dimension of women's struggles in specific situations rather than its legislative aspects. Jamal (2005) observes that bourgeois and elite women's appropriation and reconstruction of universalist and essentialized feminist ideals and ideologies in Pakistan is a counter-hegemonic move. She 
goes on to link the middle class women's activism in contemporary Pakistan against the nationalist project of Islamization a ' politically transformative moment ' (Jamal 2005, 75). Thus by challenging as well as negotiating both the patriarchal constructions of indigenous Islamization and the Western feminisms, by engaging with feminist politics and issues of religious and national identity in their specific locations, women use what Sinha (1999) terms ' rhetorical choices ' in constructing nascent forms of self-hood that are contingent on the historical conjuncture of Islamization and globalization, as well as the transnational human rights activism that has emerged in response to the political, economic and cultural dilemmas arising out of this conjuncture ( adapted from Jamal 2005).

\section{Conclusion}

The findings of this study reveal that women's lives in contemporary Pakistan are far more diverse, complex, nuanced and mutable than is generally perceived by an unempathetic, eurocentric lens. In the foregoing sections, our analysis captured useful insights into Pakistani women's multiple and shifting subjectivities, their agency, their negotiation of their Muslimness amid the Islamist discourse prevailing in Pakistan, as well as their potential role in the transnational and Islamic feminisms. While their narratives highlight the complex nature of their engagement with western feminist thinking in relation to their own identities, they also capture a level of restricted agency subliminally practiced within a constraining and restrictive social context. The research shows that in developing Muslim countries like Pakistan, women's understanding of their own identities ( religious, social, familial) and their agency and resistance are contingent upon inter-related and asymmetrical cultural relations of power within patriarchal structures, social and cultural productions.

The analysis of their narratives reveals in any case the influence feminist theories and discourses have had on these young women who wish to distance themselves from the traditional images of subservient, compliant and submissive women. Currently, they seem to be stranded at the crossroads of tradition and the new options that are available to them: 
independence and autonomy remain theoretical constructs for these women although renegotiation of their individual self is increasingly viewed as an issue by them as they realize that their private identities are not fully coherent or congruous with their communal identities and are also constantly shifting. They exhibit dichotomy and ambivalence in their aspirations: on the one hand there is desire to retain their own religious identity as opposed to the worldview implicit in English literature and feminist literature; on the other, they would like to go beyond the traditional femininities: their challenges to hegemonic constructs of Muslim women sometimes reflect the participants' engagement with mainstream feminist theory's notions of women's sexuality and sometimes diverge from it.

Furthermore, the findings show that financial independence in this context does not lead to autonomy and self-realization in making decisions in regard to marriage, employment, travelling abroad for higher education etc. and other life choices. They tend to exhibit ambivalence in their aspirations for self-development and autonomy when they contest traditional roles theoretically but practically seem to reinforce them. Unlike the radical feminists, they neither (dis)regard the institution of marriage as a form of dependence, nor do they discard family and its associated values, but appear to be struggling to find a balance between these institutions and their own personal rights and freedoms. It could be surmised from the data that the young women academics connect more with the tropes of freedom, women's rights and empowerment through education than with the term Feminism in this context. Feminism--particularly western models of feminism-- is decisively and strategically made to seem irrelevant in this context. For Pakistani women, Feminism must take a backseat now, where it might be regarded ambivalently by these young women who must-- in such public venues and spaces as described in this paper--keep a safe distance from it, for the sake of social and sexual acceptance; fear of social exclusion and losing family support as well as maintenance of their distinct religio-spiritual identities. Hence the clamour for a third epistemological space . 
Notes

1. Some texts and feminist writers women had read and/or researched on included:

White novelists: Dorris Lessing, Virginia Woolf, Gerd Brantenberg, Jean Rhys; Feminsit theory: chapters and excerpts from: Dale Spender's Man Made Language, Simone de Bouviour's The Second Sex, Elaine Showalter, Virginia Woolf's A Room of One's Own;

Women of colour and black voices: Morrison's Beloved, Bapsi Sidhwa's An American Brat, Monica Ali's Brick Lane;

Autobiography and memoirs: Maya Angelou , Tehmina Durrani and Azar Nafisi; Translated women's voices from indigenous languages: kishawar Naheed, Fehmida Riaz, Sara Shagufta, Ismat Chugtai.

2. For the group interviews, the questions were posed in English, however, the participants were allowed to code-switch in Urdu and English as most educated Pakistanis being bilingual often code-switch between Urdu and English. Some of them being more fluent in English than others, used English only.

3. Currently living in exile, the first author of this paper has suffered for teaching feminism in the form of loss of job, defamation, charges of blasphemy and blasphemous teaching. For details of what the teaching of feminism or the free expression of such ideas might entail in this context, please see Zubair ( 2016a).

4. The categories backstage and frontstage are borrowed from Goffman's work on the presentation of self in everyday life, where Goffman (1959) uses the imagery of social actors who while keeping their coherence, using different costumes and props, play out different roles in different social settings, interacting with other actors in everyday 
life. Social theorists have used the metaphor of multiplicity of identities as people play out different identities.

\section{Acknowledgements}

As the first author, I am particularly grateful to many of my colleagues at the Centre for Gender Research, University of Oslo, Norway, including Harriet Bjerrum Nielsen, AnneJorunn Berg, and Ardis Storm-Mathison for reading and commenting on an earlier draft. Also, we are particularly grateful to the two anonymous WSIF reviewers for their detailed and insightful comments.

Funding: This work was supported by funding from Berlin Graduate School Muslim Cultures \& Societies, Freie Universitat and Centre for Global Co-operation Research, Kate Hamburger Kolleg, University of Duisburg-Essen in Germany; and the Scholars- at- Risk (SAR) network in Norway and New York.

\section{References}

Aftab T (2008) Inscribing South Asian Muslim women: An annotated bibliography and research guide. Leiden: Brill.

Afzal-Khan, F. (2015) 'The politics of pity and the individual heroine sybdrome: Mukhtaran Mai and Malala Yousafzai of Pakistan,' Performing Islam 4:2, pp. 151-171, doi:10.1386/pi.4.2151_1

Alldred P (1998) Ethnography and discourse analysis: Dilemmas in representing the voices of children. In: Ribbens, J. and Rosalind, R. (eds)Feminist dilemmas in qualitative research: Public knowledge and private lives, London: Sage, pp.147-170.

Ang I (2003) 'I'm a feminist but...' Other' women and postnational feminism. In: Lewis R and Mills S (eds) Feminist Postcolonial Theory. Edinburgh: Edinburgh University Press, pp. 190-206. 
Barlas A (2013) 'Does the Qur'an Support Gender Equality? Or, do I have the autonomy to answer this question?', in Marjo Buitelaar and Monique Bernards (eds), Negotiating Autonomy and Authority in Muslim Contexts. Leuven: Peeters, pp. 1-14.

Bartkowski JP and Read JG(2003) Veiled submission: gender, power and identity among Evangelical and Muslim women in the US. Qualitative Sociology 26:71-92.

Bhabha, HK (1994) The Location of Culture. London: Routledge.

Birch M( 1998)Re/constructing research narratives: self and sociological identity in alternative settings. In: Ribbens J and Edwards R (eds) Feminist dilemmas in qualitative research, London: Sage, PP. 171-185.

Chanaria, Moon (2011)' Spectacular subjects: The violent erotics of imperial visual culture', PhD dissertation, Georgia State University, USA.

Davis DR (2010) Unmirroring pedagogies: Teaching with intersectional and transnational methods in the women and gender studies classroom. Feminist Formations 22: 136-162.

Davis K (1991) Critical sociology and gender relations. In: Davis K Leijenaar M and Oldersma J (eds) The Power of gender. London: Sage, 65-86.

Fernea, EW (1998) In Search of Islamic Feminism: One Woman's Global Journey. New York Toronto: Random House.

Foucault M( 1980) Body/Power. Gordon C (ed) Power/Knowledge: Selected interviews and other writings 1972-1977. NewYork: Pantheon Books, pp. 55-62.

Giddens A (1994) Modernity and self identity: Self and society in late modern age. Cambridge: Polity.

Gilligan C (1990) Prologue. In: Gilligan C Lyons NPand Hanmer TJ (eds) Making Connections: The Relational Worlds of Adolescent Girls at Emma Willard School. Cambridge, MA: Harvard University.

Goffman E (1959)The presentation of self in everyday life. New York: Doubleday. 
Hassan R(1992) Muslim women and post-patrirachal Islam.In: Cooey PM Eakin WR and McDaniel JB (eds) After patriarchy: Feminist transformations of the world religions.

NY: Orbis, pp. 39-64.

Jamal A (2005) Transnational feminism as critical practice: A reading of feminist discourses in Pakistan. Meridians: Feminism, Race, Transnationalism, 5(2): 57-82.

(2009) Gendered Islam and modernity in the nation-space: women's modernism in the Jamaat-e-Islami of Pakistan. Feminist Review, 91:9-28.

Jeffery, P ( 1979) Frogs in a Well: Indian Women in Purdah. London: Zed Press.

Khan S (1998) Muslim women: Negotiations in the third space. Signs, 23(2): 463-494.

Khan S (2004) Locating the Feminist Voice: The Debate on Zina Laws in Pakistan, Feminist Studies, Vol 30(3): 660-685.

Khan S (2010) Locating the feminist voice: The debate on the zina ordinance.In Ahmed S (ed)Pakistani women: Multiple locations and competing narratives. Karachi:Oxford, pp. 176-192.

Khurshid A (2015) Islamic traditions of modernity: Gender, class, and Islam in a transnational women's education project. Gender \& Society 29(1):98-121.

Lewis R and Mills S (2003) (eds) Feminist Postcolonial Theory, Edinburgh: Edinburgh University Press.

Loomba A (2003) Dead women tell no tales: issues of female subjectivity, subaltern agency and tradition in colonial and postcolonial writings on widow immolation in India. In: LewisR. and Mills S (eds) Feminist Postcolonial Theory, Edinburgh: Edinburgh University Press, pp. 241-262.

Mahmood S (2005) Politics of Piety: The Islamic Revival and the Feminist Subject. Princeton: Princeton University Press. 
Mai M , translated by Coverdale, L (2007) In the name of Honour: A Memoir. Washington: Washington Square Press.

McRobbie A (2009) Postfeminism and popular culture: Bridget Jones and the new gender regime. Feminist Media Studies, 4(3)11-23.

Mendoza B (2002) Transnational feminisms in question. Feminist Theory, 3(3) : 313-332.

Mernissi F ( 1987) Beyond the veil: Male-female Dynamics in Modern Muslim Society. Bloomington: Indiana University Press.

Metcalf BD (2002) Perfecting women: Maulana Ashraf Ali Thanawi's Bihishti Zevar.New Delhi: Oxford.

Mohanty CT (1988) Under Western eyes: Feminist scholarship and colonial discourses' Feminist Review, 30:65-88.

Mouffe, C. (1993) Feminism, citizenship and radical democratic politics. In The Return of the Political. London, New York: Verso, pp. 74-89.

Neitz MJ(2004) Gender and culture: Challenges to the sociology of religion.Sociology of Religion, 65: 391-402.

Parr J( 1998) Theoretical voices and women's own voices. In: Ribbens J and Edwards R (eds)Feminist Dilemma's in Qualitative Research. London: Sage, pp. 87-101. (2000)Identity and Education: The Links for Mature Women Students.

Burlington Singapore and Sydney: Ashgate

Read JG and Bartkowski JP ( 2000) To veil or not to veil? A study of identity negotiation among Muslim women in Austin, Texas.Gender \& Society 14:395-417.

Schneider NC (2009)Islamic feminism and Muslim women's rights activism in India: from transnational discourse to local movement-or vice versa?Journal of International Women's Studies11(1):pp56-71. 
Sinha M (1999) 'The lineage off the Indian Modern: Rhetoric, Agency and the Sarda Act Late Colonial India'. In Antoinette Burton (ed.) Gender, Sexuality and Colonial Modernities. London: Routledge, pp 207-21.

Spender D (1985)Man Made Language.London: Routledge

Spivak GC (1988) Can the subaltern speak? In: Nelson C and Grossberg L (eds)Marxism and the Interpretation of culture.Urbana: University of Illinois Press.

Willett R(2008) Consumer citizens online: Structure agency and gender in online participation. In: Buckingham D (ed) Youth Identity and Digital Media. Cambridge MA: MIT Press.

Wuthnow RJ( 2011) Taking talk seriously: Religious discourse as social practice.Journal of the scientific study of religion 50:1-21.

Yousafzai M and Lamb C (2013) I Am Malala: The Girl Who Stood Up for Education and was Shot by the Taliban. London: Weidenfeld \& Nicolson.

Zia AS (2009) The reinvention of Feminism in Pakistan.Feminist Review, 91:29-46.

Zubair S (2006) Women English Literature and Identity Construction in Southern Punjab, Pakistan. Journal of South Asian Development, 1.1 :249-271 (2016a) Theorizing Institutional Feelings, Bodies and Spaces: the Case of Feminisms and Women's Studies in Pakistan, Feminist Formations $28.3: 95-120$.

(2016 b) Development Narratives, Women and Media in Pakistan: Shifts and Continuities, South Asian Popular Culture, 14:1-2 :19-32.

\section{Websites:}

www.Raihaneh.com 'Islamic feminism in the Middle East (3)'. Accessed 13/4/2016. 
Saigol, R. (2016) Feminism and the Women's Movement in Pakistan: Actors, Debates and Strategies. Friedrich-Ebert Stiftung: Germany. PP. 33-34.

http://www2.fes-asia.org/feminism-and-the-womens-movement-in-pakistan-2/ Accessed 3/5/2017. 